\title{
SUPPORTIVE METHODS FOR ASSESSING EFFECTIVE POROSITY AND REGULATING KARST AQUIFERS
}

\author{
POMOŽNE METODE ZA OCENJEVANJE EFEKTIVNE \\ POROZNOSTI TER REGULIRANJE KRAŠKIH VODONOSNIKOV
}

\author{
Zoran STEVANOVIC, Sasa MILANOVIC \& Vesna RISTIC ${ }^{1}$
}

\begin{abstract}
UDC 556.33:519.216

Zoran Stevanovic, Sasa Milanovic \& Vesna Ristic: Supportive methods for assessing effective porosity and regulating karst aquifers

Regulation of a karst aquifer implies engineering interventions designed to control its flow and manage its water reserves. One of the most important prerequisites for the feasibility and success of regulation projects is proper assessment of aquifer effective porosity (storativity) and accumulated groundwater reserves. This paper is focused on several specific methods which can contribute to a reliable assessment of the size and volume of effective storage in karst: cave diving survey, camera logging of cavities, stochastic analysis of discharge regime and 3D modelling of karst interior. The application of these methods on selected test sites in Montenegro, Algeria and Serbia are described. These methods were applied as part of the research programme conducted in the catchment of Mlava Spring, the largest spring in the Carpathian karst of Serbia. The results obtained by the stochastic analyses of the spring's discharge regime, as well as siphon diving of the spring and 3D modelling for reconstruction of conduits networks in karst interior are particularly important.
\end{abstract}

Keywords: karst aquifer regulation, effective porosity, cave diving, camera recording, stochastic analysis, 3D conduits modelling.

\section{Povzetek \\ UDK 556.33:519.216 \\ Zoran Stevanovic, Sasa Milanovic \& Vesna Ristic: Pomožne metode za ocenjevanje efektivne poroznosti ter reguliranje kraških vodonosnikov}

Regulacija kraškega vodonosnika obsega inženirsko posredovanje $\mathrm{z}$ namenom nadzorovati pretok voda ter upravljati vodne zaloge. Eden najpomembnejših pogojev za izvedljivost in uspešnost regulacijskih projektov je prava ocena efektivne poroznosti vodonosnika (uskladiščenje) ter akumuliranih zalog podzemne vode. Ta članek je osredotočen na nekaj določenih metod, ki lahko prispevajo k zanesljivi oceni obsega in prostornine efektivnega uskladiščenja $\mathrm{v}$ krasu: potapljaške raziskave jam, merjenje votlin s kamero, stohastične analize pretočnega režima in $3 \mathrm{D}$ modeliranje kraške notranjosti. Opisane so aplikacije teh metod na izbranih testnih območjih v Črni gori, Alžiriji in Srbiji. Te metode so bile uporabljene kot del raziskovalnega programa, ki je bil izveden $\mathrm{v}$ zaledju največjega izvira karpatskega krasa v Srbiji, izvira Mlava. Rezultati dobljeni s stohastičnimi analizami pretočnega režima na izviru, potapljaškimi raziskavami izvirskega sifona in 3D modeliranjem za rekonstrukcijo mreže kanalov v kraški notranjosti, so še posebej pomembni.

Ključne besede: regulacija kraškega vodonosnika, efektivna poroznost, jamarsko potapljanje, snemanje s kamero, stohastične analize, 3D kanalsko modeliranje.

\section{INTRODUCTION}

The result of regulating or controlling the groundwater in karst aquifer should be analogous to managing the water resource of an open reservoir. For the latter, the volume of the reservoir, i.e., storage, is not difficult to calculate, but a system of fissures, channels and caverns within karst aquifer and thus water availability can be estimated only

\footnotetext{
${ }^{1}$ Department of Hydrogeology (Centre for Karst Hydrogeology), University of Belgrade - Faculty of Mining and Geology, Serbia, e-mail: zstev@eunet.rs
}

Received/Prejeto: 2.12.2009 
from results of specialized research methods. Particularly problematic is the evaluation of the aquifer's deeper saturated geometry.

The term storativity or storage coefficient is not often discussed in karst studies. It is, though, commonly evaluated as one of the main hydraulic parameters of intergranular aquifer (Kresic 2007), because the classical methods of assessing storativity after pumping tests do not provide successful results in the case of karst. Moreover, decompressibility effects of confined karst aquifers are insignificant in comparison with those characterizing the intergranular media.

The storativity in karst could be considered relative to the effective porosity, which is regularly referred to as a term in karst hydrogeology. Knowledge of it is essential for calculating geological water reserves and for assuming a storage space when planned interventions intend to increase the aquifer's water table.

Whereas the classical underground flow tapping by water wells or by intakes which gather the natural yield is not complicated by definition, the design and construction of specific regulation structures such as underground reservoirs is more delicate (Kresic 2010). To ensure the success of the latter, several steps are recommended (complex and multiphase explorations, studies, design).

Regulation of an aquifer requires knowledge of the following characteristics (Stevanovic 2010):

- aquifer's catchment,

- discharge regime,

- groundwater table fluctuations,

- depth to karstification base,

- aquifer storativity.

Assuming the approximate volume of accumulated water in the deeper part of the aquifer increases the chances for a successful regulation project. For instance, in the Carpathian karst there are several aquifers with a highly karstified net of channels to a depth of 70-120 m, or even deeper that after extensive exploration have been successfully regulated (Kullman \& Hanzel 1994; Stevanovic \& Dragisic 1997; Stevanovic et al. 2007). The majority of implemented projects concerned a battery of drilled wells, galleries and pumped siphons (in the case of ascending, vauclusian springs).

The construction of underground dams is the most complicated and expensive among regulation projects. The calculation of both saturated and unsaturated storage is important in planning underground dams which by definition aim to increase the groundwater table and establish a new reservoir in the upper aquifer parts (vadose or temporary saturated zones). There have been several such projects designed or experiments conducted in the Dinaric karst (Peric et al. 1980; Milanovic P. 2000). These were designed on the basis of approximated storativity values, and other explored sites. The preliminary design of several proposed underground reservoirs took into account the storativity values ranking between 0.01 - 0.02. The main practical experience has been obtained from the implementation of such projects in China. There, some 20 underground reservoirs have been completed for different purposes (water supply, irrigation, hydropower) and enable water storage ranging from $1 \mathrm{x}$ $10^{5} \mathrm{~m}^{3}$ to $1 \times 10^{7} \mathrm{~m}^{3}$ in each of them (Yaoru et al. 1973).

The general methodology of hydrogeological exploration in karst is well described (Milanovic P. 1979; Goldscheider \& Drew 2007, Ford \& Williams 2007). However, for specific tasks some methods should be prioritized by taking into account their efficiency and cost. For assessment of effective porosity two major groups of methods can be distinguished:

- Direct (when contact with karst interior is established)

- Speleology,

- Cave diving into karst siphons,

- Camera recording and logging into boreholes,

- ROV (remote-controlled vehicle),

- Core drilling and water injection tests.

- Indirect (based on interpretation of in-field collected data)

- Tracing tests,

- Geophysical methods,

- Hydrodynamic analysis of pumping tests,

- Stochastic analysis of spring discharge hydrograph,

- 3D modelling for reconstruction of karst physical interior (GIS).

Methods such as tracing tests or geophysical surveys, are "classical" and have been included in the majority of conducted karst studies. For this reason in this paper we have focused more on infrequently applied techniques. New technologies and innovations during the last few decades have provided new opportunities for diving in caves or for use of small cameras, as well as for stochastic and GIS desk analyses. The results obtained from a number of projects confirm their potential to integrate with engineering projects in karst. 


\section{DIVING EXPLORATION OF KARSTIC SPRING SOPOT (MONTENEGRO)}

\section{GENERAL PROBLEM}

Tapping the fresh groundwater in littoral karst is one of the main challenges for hydrogeologists worldwide. If karst is in direct contact with salt water intrusion, then its saline content depends mostly on the extraction rate. Examples from Caribbean karst (Merida at Yucatan Peninsula, Mexico; Jamaica; Puerto Rico) or Mediterranean karst (Crete, Greece; Marseille, France; Lebanon or the Libyan coast) are just some of the very well known ones (Potie \& Tardieu 1977; Escolero et al. 2002; Mijatovic 2005).

The two main targets in littoral karst studies aiming to tap freshwater are: locating the main conduits conveying groundwater flow; and mapping the natural impermeable barrier (if one exists). Most commonly, research programmes comprise tracing tests, geophysical surveys, exploratory drilling (and pumping) and speleology/diving exploration. Once the karst interior is estimated, the conceptual model of the hydraulic relationship between sea and fresh waters could be created. Moreover, if there is sufficient data for creating the mathematical model a sustainable groundwater extraction rate could also be estimated. The possible natural barrier is nevertheless important: it could facilitate the design and be part of an engineering solution (Milanovic P. 2000).

Tracing tests provide highly valuable indirect data about karst reservoirs (Käss 1998; Goldscheider \& Drew 2007; Goldscheider et al. 2008). Where geophysical methods are concerned some recent experiences with spontaneous potential (Stevanovic \& Dragisic 1998), induced polarization, electric resistance tomography, or very low frequency, show more advantages than does the application of the standard resistivity method. Speleology in the upper accessible parts of karst and diving into saturated parts has a very long tradition, a tradition as long, in fact, as the history of karst hydrogeology (Cvijic 1893).

There are many projects in which divers have mapped karst interior, recorded stratigraphy, fracture zones and larger phreatic passages, estimated the volume of a reservoir and its potential, and above all traced the position of subterranean channels to select the appropriate position for pumps to be installed later (Avias 1984; Toulomudjian 2005; Milanovic S. 2005).

Whilst there are many advantages to the cave diving method, there are also limitations. Cave diving survey has associated risks and is only for those who are well trained and experienced. Among the main problems are: the inability to explore less than body sized phreatic leads, limited exploration of depth without special de- compression tools, potential low visibility and increased flow during flood events. However, the risks can be greatly reduced by special training and methods such as the use of Trimix (helium and $\mathrm{O}_{2}$ ), decompression gases (Nitrox) and Closed Circuit Rebreathers (CCR), the establishment of fixed survey lines, and the use of multiple bale out cylinders.

\section{TEST SITE: SOPOT SPRING (MONTENEGRO)}

The spring is situated on the shoreline of the Adriatic Sea in the beautiful bay of Boka Kotorska near the city of Risan (Fig 1). The Orjen Mt. catchment is characterized by the highest precipitation rate in Europe (average annual 3,000 - 5,000 mm). The Mesozoic limestones exposed at the surface are extremely karstified without any surface flows (infiltration capacity is over $80 \%$ ). At the "Stone Sea" area of $8 \mathrm{~km}^{2}$ more than 300 vertical shafts are registered (Milanovic P. 2005). Some of those shafts were speleologically investigated to depths between 200 and $350 \mathrm{~m}$.

The main Sopot drainage channel is only periodically active. The maximal discharge from the cave situated some $50 \mathrm{~m}$ above sea level (asl) can reach an extremely large flow of $200 \mathrm{~m}^{3} / \mathrm{s}$, while during the summer and autumn months the water table is depleted and only submarine channels are active (Fig. 1).

\section{PURPOSE OF STUDY AND CHOSEN METHOD}

In spite of enormous precipitation only a small amount of potable groundwater is successfully tapped along Boka Kotorska: $1 \%$ of the groundwater potential is actively used (Milanovic P. 2005). As a prelude to the conceptual engineering design to tap the spring water, it was necessary to address the:

- orientation and size of saturated channels,

- availability and storage of fresh water,

- distance of salt water intrusion,

- presence of impermeable layer (Eocene flysch).

The initial survey includes a combination of speleology and diving as the most efficient and appropriate methods, including water sampling and analyses (Milanovic S. 2007). The lower flow conditions during late summer were chosen for the safety of explorers, in addition the minimal discharge from the karst coincides with periods of highest water demands. Therefore, the undisturbed salty - fresh water relationship during the dry season was found to be an indicator of a much worse situation when exploitation of the aquifer would start. 


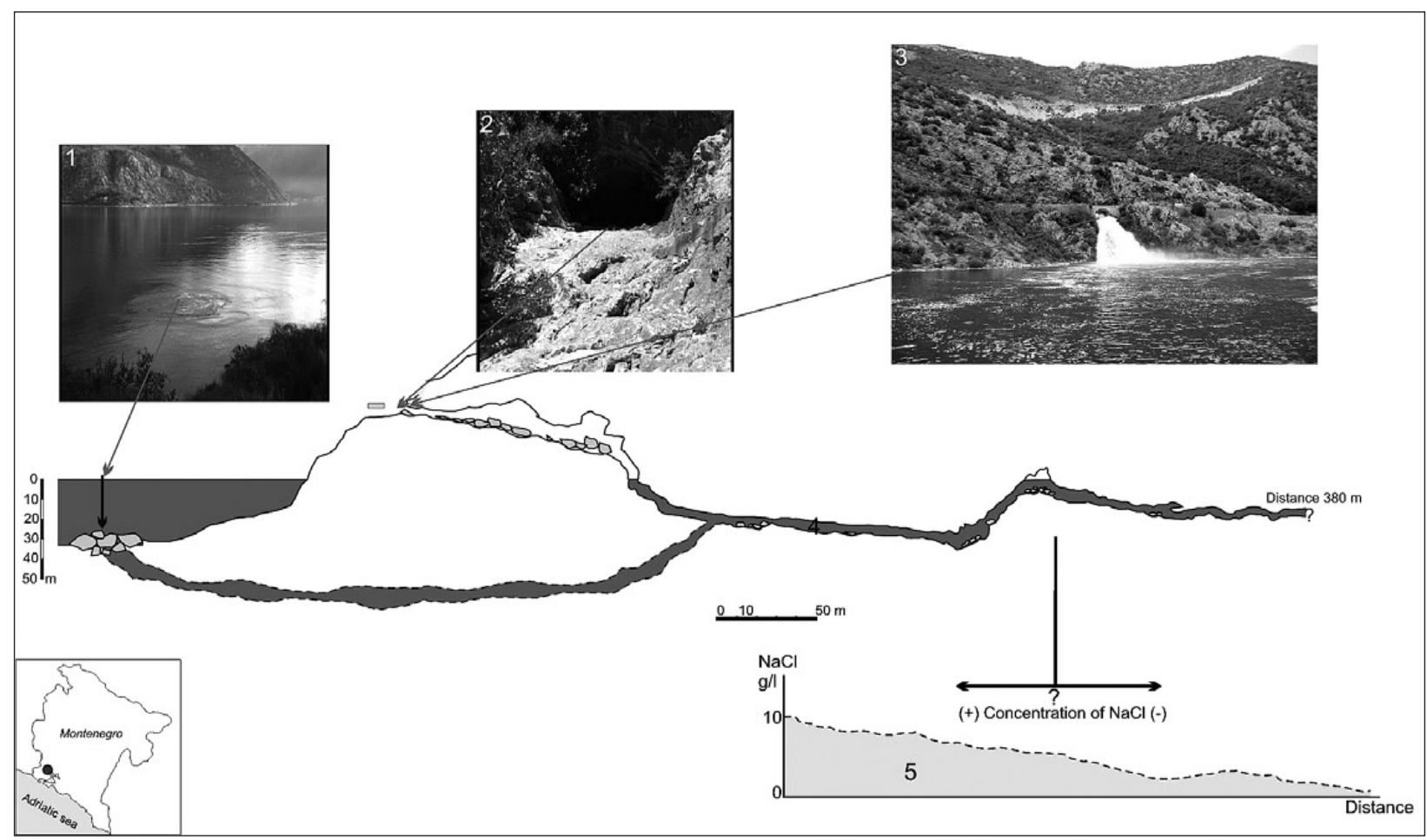

Fig. 1: Complex cave system of Sopot spring (submarine and overflow discharge) in Boka Kotorska bay (modified after Milanovic S. 2007, Photos: S. Milanovic). Legend: 1. submarine drainage, 2. main cave entrance, 3. active drainage from cave during the flood episode, 4. main drainage channel, 5. NaCl content along main channel (in $\mathrm{g} / \mathrm{l}$ ).

\section{RESULTS AND DISCUSSION}

The Sopot Spring cave consists of two main superimposed channels connected in the deeper part of the aquifer. Those channels are partly investigated and partly reconstructed. Their rectilinear length is $380 \mathrm{~m}$ from the cave opening. During the lower flow period the groundwater samples were collected along the impounded channel. The maximal registered value of $\mathrm{NaCl}$ was $10 \mathrm{~g} / \mathrm{l}$ recorded at the crossing point of the two channels (Fig. 1). Further inland, $\mathrm{NaCl}$ gradually reduced but brackish waters $(>1 \mathrm{~g} / \mathrm{l})$ were still present at $250 \mathrm{~m}$ from the entrance (Fig. 1). Towards the $380 \mathrm{~m}$ mark the fresh water becomes more dominant. First of all, the survey confirmed welldeveloped karst and a good storage potential. However the results did not favour an uncomplicated regulation project and intake for the following reasons:

1. No impermeable flysch layers were found either at the sea bottom or inside the explored cave (the barrier is deep under the sea and distant from the spring);

2. The interface of salty-fresh water is located deep inside the channel, and would most probably be extended during critical dry periods;
3. The position and connection of channels does not allow easy grouting or sealing, possible options to separate sea from fresh waters;

4. The lateral secondary channels noticed during the exploration are potential pathways for huge losses if the dam and underground reservoir are proposed for storage of Orjen flood waters;

5. The huge pressure from the water column during flood episodes requires significant enforcement of any possibly impermeable structure to prevent its collapse;

6 . Finally, any attempt to pump fresh water will definitely cause more severe intrusion of sea waters.

Similar results obtained at other locations along the Montenegro coast have led to the prioritization in the national Water Master Plan of the water supply from distant continental parts. 


\section{CAMERA RECORDING OF CAVITIES AT OURKISS DAM SITE (ALGERIA)}

\section{GENERAL PROBLEM}

The water-tightness of the reservoir in karst is the key element for its successful construction and operation. An extensive exploration programme prior to the dam construction can minimize groundwater losses to acceptable levels (Milanovic P. 2000; Ford \& Williams 2007; Milanovic S. et al. 2010). The experience with Dinaric karst in the 1960s and 1970s when several large projects were successfully implemented in the former Yugoslavia was of great significance for the promotion of such projects worldwide.

The remedial measures can include among others: a grouting curtain, an impermeable blanket, sealing works. The choice of application depends on local conditions: apart from artificial factors such as the type of dam construction and water level (pressure to the reservoir's bottom), the degree of karstification and created conduit network are most important.

It was determined that water permeability (injection) tests are most commonly applied for effective porosity assessment, whilst remote sensing and geoelectrical surveying provide validation. Specific techniques such as geo-bombs have been tested first in these projects (Milanovic P. 1979).

Concerning the direct identification of cavities inside the drilled boreholes, the primary methods up to the 1970s were down-the-hole geophysical logging and calipers. Today, small-size cameras allow much more accuracy and flexibility. A camera can be installed into the boreholes in both the saturated and unsaturated parts of the aquifer, and in any open fissure with a diameter larger than that of the camera $(\sim 50 \mathrm{~mm})$. The limitations are: 1 . photos or videos provide only relative indications of cavernous porosity; 2 . although powerful, the lamp can be still insufficient to light the furthermost or curved parts. Nonetheless, these methods provide better insight and orient further research.

The ROV (remote-controlled vehicle) supported by video camera (Fig. 2) can be useful for large saturated channels where access by humans is otherwise restricted. There are several such autonomous underwater vehicles primarily constructed for deep marine exploration (Lapierre 2008).

\section{TEST SITE: OURKISS DAM (ALGERIA)}

The Ourkiss dam site is located $5 \mathrm{~km}$ from the city Oum el Bouaghi (NE Algeria) at the entrance of the Oued Ourkiss gorge. Oued Ourkiss is one of the tributaries of the salty lake Garaet el Guelif. The designed reservoir at the altitude of $951 \mathrm{~m}$ asl will store the waters of the temporary Oued Ourkiss stream, but over $90 \%$ will be water pumped from another reservoir, the Oued Athmenia, and chanelled to the Ourkiss basin during the flood periods (Fig. 3). The wide valley inside the future reservoir consists of Mio-Pliocene and Quaternary deposits which overlie the Albian and Aptian well karstified limestones. At the dam site limestone outcrops are present at the both Oued's banks. A rock-filled dam with clay core is designed.

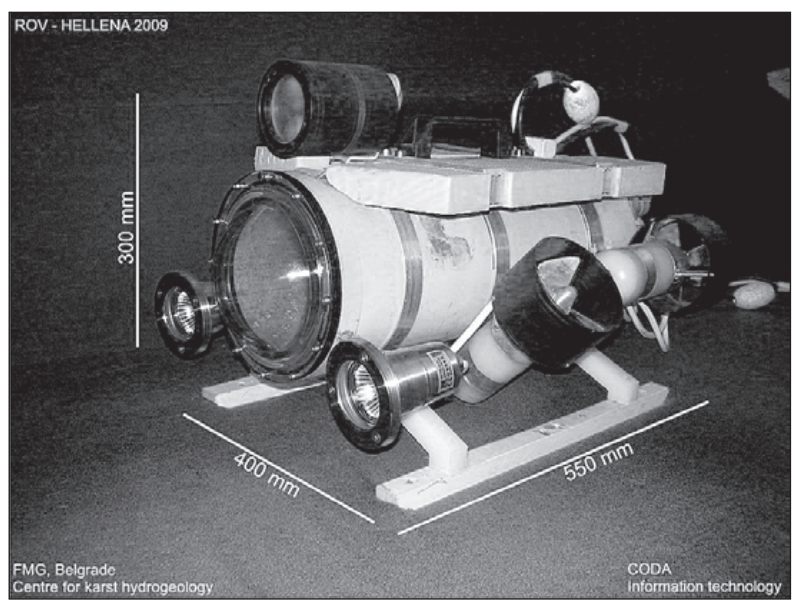

Fig. 2: Specially constructed remote-controlled vehicle (ROV) equipped with camera for underwater exploration (model FMG - CODA, Belgrade, Photo: S. Milanovic)

\section{PURPOSE OF STUDY AND CHOSEN METHOD}

The geological setting indicated possible water losses from a new reservoir: the karstified core samples, very permeable layers according to injection tests and open faults, were some of the main warning symptoms. Furthermore, during one flood a large quantity of water sank into a previously undiscovered ponor. In order to collect data for possible protective measures Milanovic P. et al. (2007) have defined an initial programme. Among other methods, camera recording of the boreholes drilled on embankments and inside the future reservoir is proposed.

A survey of cavities has been conducted with a small multi-angle camera developed at the Centre for Karst Hydrogeology FMG, Belgrade (Fig. 3).

\section{RESULTS AND DISCUSSION}

The inventory comprises a large number of cavities, in total 460 in ten surveyed boreholes (Tab. 1). Most of these 


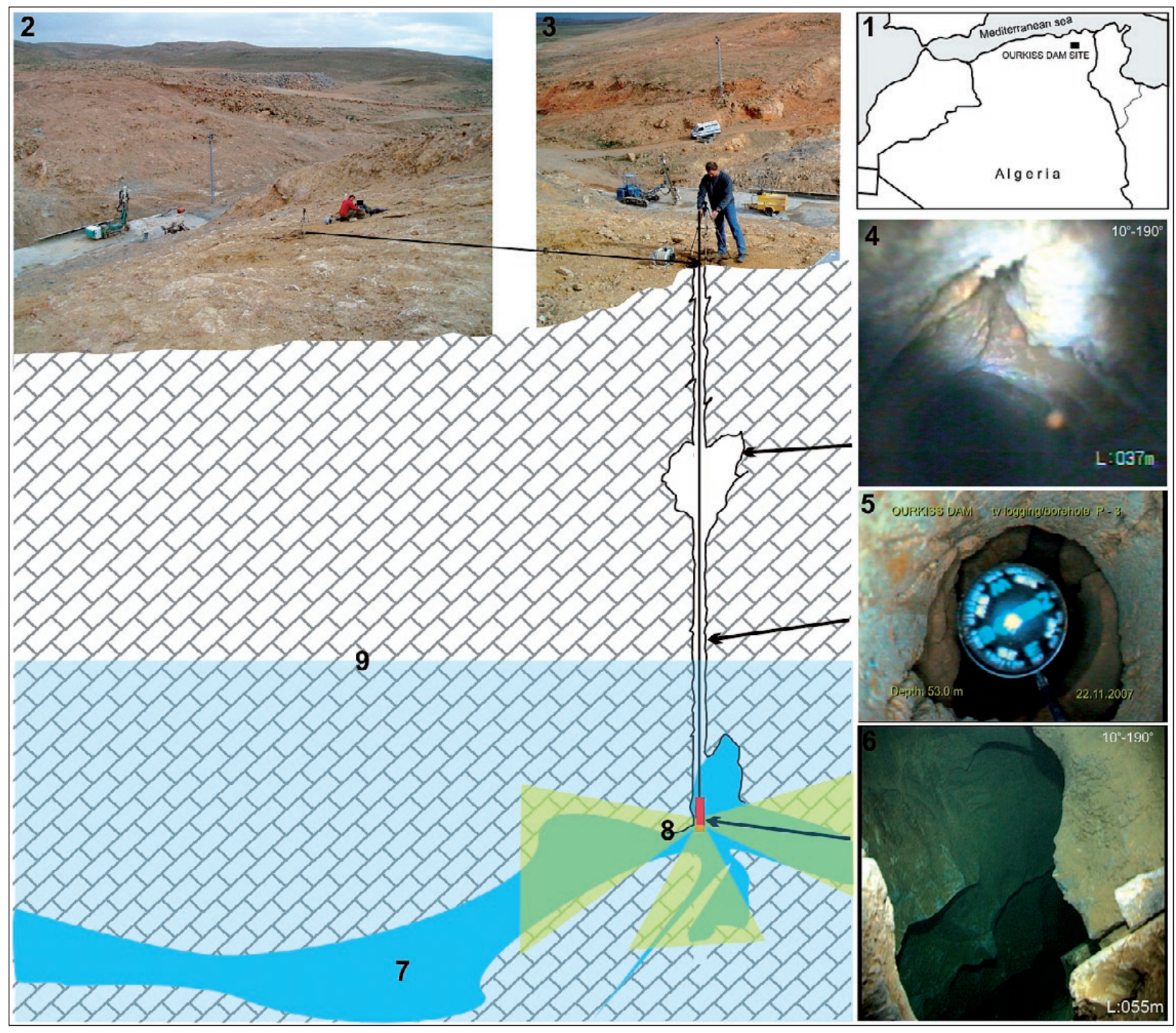

Fig. 3: Camera log records from the Ourkiss dam site (Algeria; Photos: S. Milanovic). Legend: 1. location map, 2. dam site, 3. surveyed borehole, 4. recorded fissure at $37 \mathrm{~m}$ depth, 5. vertical view, 6. karst channel at $55 \mathrm{~m}$, 7. main cavern, 8. camera lens angle $90^{\circ}$, 9. Aptian limestone.

cavities are currently above maximal groundwater table, but will be fully impounded after the reservoir filling.

Based on this survey the sealing of the main ponor and the building of an impermeable clayey blanket in the wider reservoir area to cover all limestone outcrops are proposed.

The Ourkiss cave system would not be fully explored by using conventional geophysics or other methods for the following reasons:

- The caliper's bars are too short to record the size of cavities.

- Tracing tests provide valuable information through recorded velocities or tracer quantitative analy- ses, but cannot be successfully conducted in unsaturated parts.

- Good information about the size and volume of empty space in karst interior is obtained by a water injection test but there are also many obstacles. For example, a large amount of water can be absorbed even by a small, but well-connected fissure system. Therefore, registered water losses by the classical test do not provide sufficient data to distinguish enormous from medium size or even small cavities. 
Tab. 1: The results of camera recording of karst conduit network at Ourkiss dam site (November 2007).

\begin{tabular}{|l|c|c|c|c|c|c|c|c|}
\hline Bore-hole & $\begin{array}{c}\text { Elevation } \\
\text { m asl }\end{array}$ & $\begin{array}{c}\text { Bore-hole } \\
\text { depth } \\
(\boldsymbol{m})\end{array}$ & $\begin{array}{c}\text { GWL } \\
\mathbf{m} \text { asl }\end{array}$ & $\begin{array}{c}\text { No. of karstified } \\
\text { intervals }\end{array}$ & $\begin{array}{c}\text { General } \\
\text { direction } \\
/ 0\end{array}$ & $\begin{array}{c}\text { Max. } \\
\text { length } \\
(\mathbf{m})\end{array}$ & $\begin{array}{c}\text { Min. } \\
\text { length } \\
(\boldsymbol{m})\end{array}$ & $\begin{array}{c}\text { Approx. } \\
\text { calculated } \\
\text { porosity } \\
\%\end{array}$ \\
\hline P2 & 919.57 & 62 & & 28 & $325-335$ & 9 & 0.1 & 12.1 \\
\hline P3 & 923.62 & 67 & 863.62 & 19 & $335-360$ & 4 & 0.3 & 7.3 \\
\hline P4 & 939.13 & 85 & 854.13 & 22 & $300-325$ & 5 & 0.2 & 8.2 \\
\hline R1 & 924.5 & 74 & & 16 & $295-318$ & 4 & 0.25 & 4.1 \\
\hline R2 & 913.75 & 50 & 863.75 & 14 & $310-322$ & 3 & 0.1 & 1.9 \\
\hline R3 & 932.35 & 60 & & 19 & $288-303$ & 3 & 0.1 & 2.2 \\
\hline R4 & 932.65 & 78 & 857.65 & 17 & $310-340$ & 2 & 0.05 & 1.5 \\
\hline GD-III-25 & 921.25 & 33 & & 9 & $312-345$ & 3 & 0.2 & 1.7 \\
\hline GD-III-30 & 921.08 & 37.5 & & 4 & $300-330$ & 2 & 0.3 & 1.8 \\
\hline GD-III-35 & 920.97 & 42 & & 5 & $290-325$ & 3 & 0.25 & 2.1 \\
\hline
\end{tabular}

\section{STOCHASTIC ANALYSES OF DISCHARGE REGIME OF KARSTIC SPRING VELIKO VRELO (SERBIA)}

\section{GENERAL PROBLEM}

Stochastic analysis of spring hydrographs is one of the most valuable indirect methods. The method of time series (autocorrelation and cross-correlation) analyses was initially developed with the aim of characterizing a karst aquifer (Mangin 1984; Bonacci 1993; Kresic 2007; Ristic 2007). Using a distribution-transformation function, precipitation can be converted into a hydrogram of karst spring daily discharges.

In many recent karst studies dealing with stochastic models there are two dominant types of karst systems: 1. Poorly developed karst systems with large storage capacity (diffuse), or 2. Well-developed karst aquifer with larger conduits but without significant storage of water (Atkinson 1977; Bonacci 1993; Padilla et al. 1994; Panagopoulos \& Lambrakis 2006). In contrast to these two, large storage capacity phreatic reservoirs in highly karstified limestones, such as those of Yucatan are neither evaluated often, nor classified. However, the method is of great significance not only for modelling and predicting karst system behavior, but also for assessing and managing the water resources.

\section{TEST SITE: VELIKO VRELO (SERBIA)}

Veliko (Great) Vrelo (Spring) is one of the major springs in the Carpathian karst of eastern Serbia (Upper Resava River catchment). This typical gravity spring drains massive Tithonian limestones. A few hundred meters from discharge points one of the most beautiful waterfalls has formed, and today is protected as a Natural Monument (Fig. 4). The spring discharge varies from $0.1-2.5 \mathrm{~m}^{3} / \mathrm{s}$.

\section{PURPOSE OF STUDY AND CHOSEN METHOD}

Due to its geoheritage importance the spring is one of the tourist sites in this part of Serbia which attracts many visitors and generates local income. The conducted survey was primarily aimed at estimating the spring's minimal flow and judging if some small amount can be utilized for local purposes without disturbing ecological and ambient demands. In addition, delineation of its catchment was required for sanitary protection.

Along with field hydrogeological mapping, speleological survey and tracing tests in the mountainous area of the Upper Resava, the stochastic analyses and modelling were also undertaken.

The opportunity was also taken to test a new method for calculating surface area based on discharge regime analysis (Ristic 2007). The method includes several steps:

- Initially, the cross correlation of recorded daily discharge values and rainfalls should be established as in classical stochastic analysis.

- As a next step the stochastic model for springflow simulation could be created, which includes the assess- 


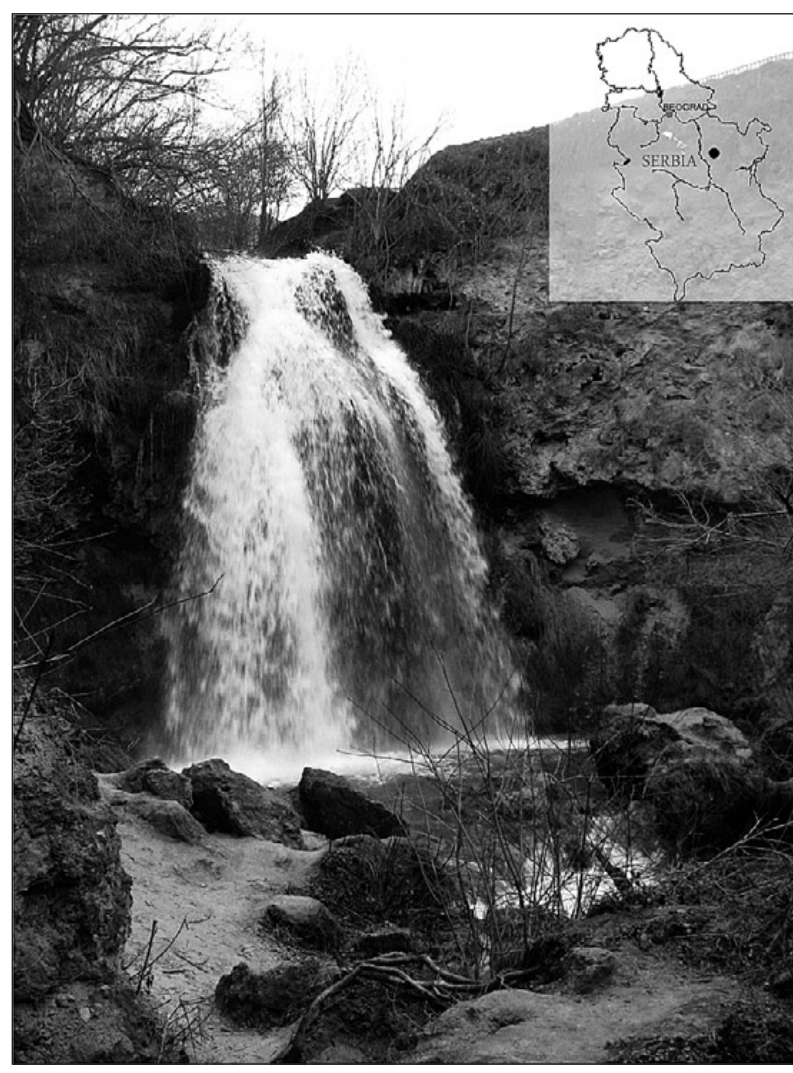

Fig. 4: Waterfall of Veliko Vrelo on thick travertine deposits (Photo: Z. Stevanovic).

mass curve could be used to assess the multi-annual cyclicity of hydrometeorological events and processes. A graphical interpretation of this curve shows the alternating wet and dry years. A positive increment of the function $f(\mathrm{t})$ characterizes a wet period, while a negative is typical of a dry period.

- The daily sums of potential evapotranspiration (PET) from the karst based on the modified Thornthwaite equation (Prohaska 2003) should then be approximated. The next step is calibration of the water budget equation, after which the daily sums of the actual (real) evapotranspiration can be obtained.

- The model is based on the following assumptions (Ristic 2007):

1. The initial volume of water stored in a karst aquifer is equal to the volume at the end of the reference period:

$$
v_{\mathrm{o}} \cong v_{\mathrm{k}}
$$

where $v_{\mathrm{o}}$ is initial volume, and $v_{\mathrm{k}}$ volume at the end of the reference period.

2. The distribution of daily sums of actual ("real") evapotranspiration is non-linear: for rainy days, the values derived for daily sums of potential evapotranspiration are considered to be the actual (real) daily sums, while for subsequent non-rainy days the actual (real) daily sum of evapotranspi-

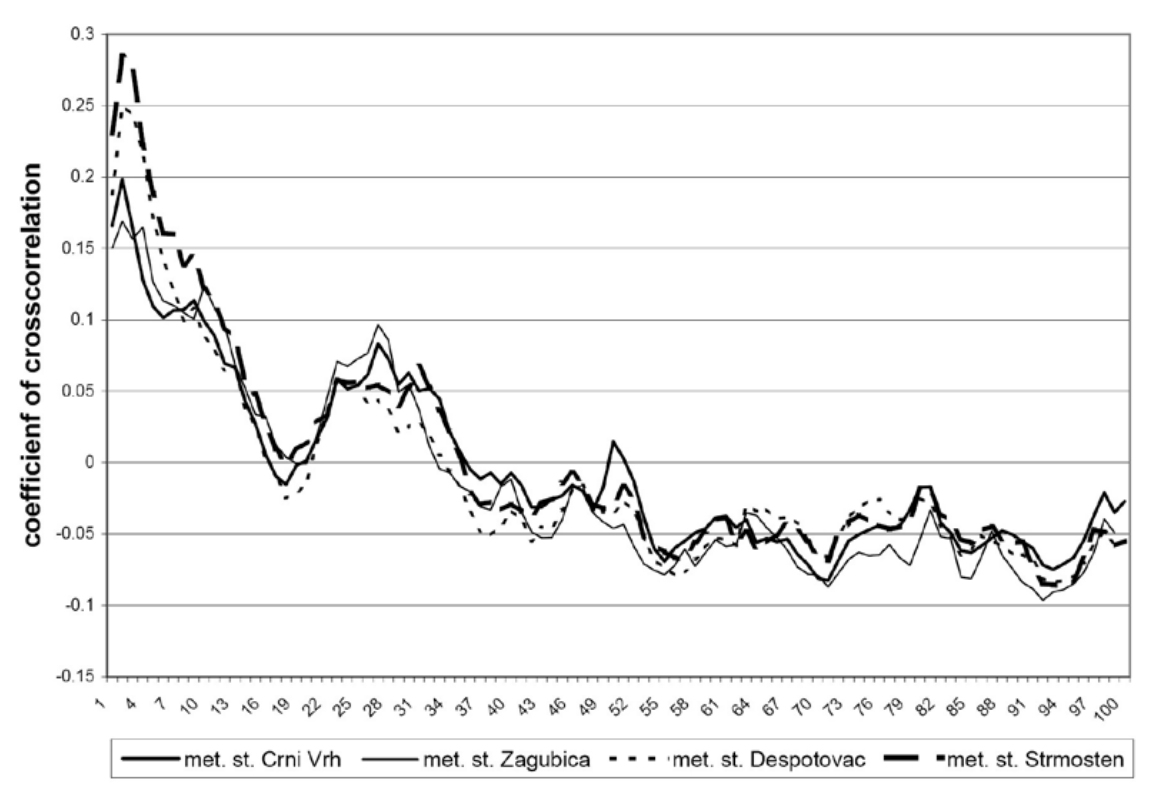

Fig. 5: Cross-correlogram of daily discharges of the Veliko Vrelo spring and precipitation recorded by four rain-gauging/weather stations. ration declines based on the following equation:

$$
E_{j(k+\tau)}=\Theta^{2 \tau} \cdot P E T_{i k}
$$

where:

$E_{j(k+\tau)}=$ actual total daily evapotranspiration $[\mathrm{mm}]$;

$\tau=1,2,3, \ldots$, is the time step in days;

$\Theta=0,0.1,0.2, \ldots 0.9,0.95$ is a non-dimensional coefficient which represents reduction of evapotranspiration after the rainfall;

$P E T_{i k}=$ potential sums of daily evapotranspiration $[\mathrm{mm}]$.

3. Catchment area ment of the geometry of the aquifer and water budget elements. A mean annual discharge modulus deviation sizes vary depending on values of $\Theta$, based on the rule $v_{\mathrm{o}} \cong v_{\mathrm{k}}$. 


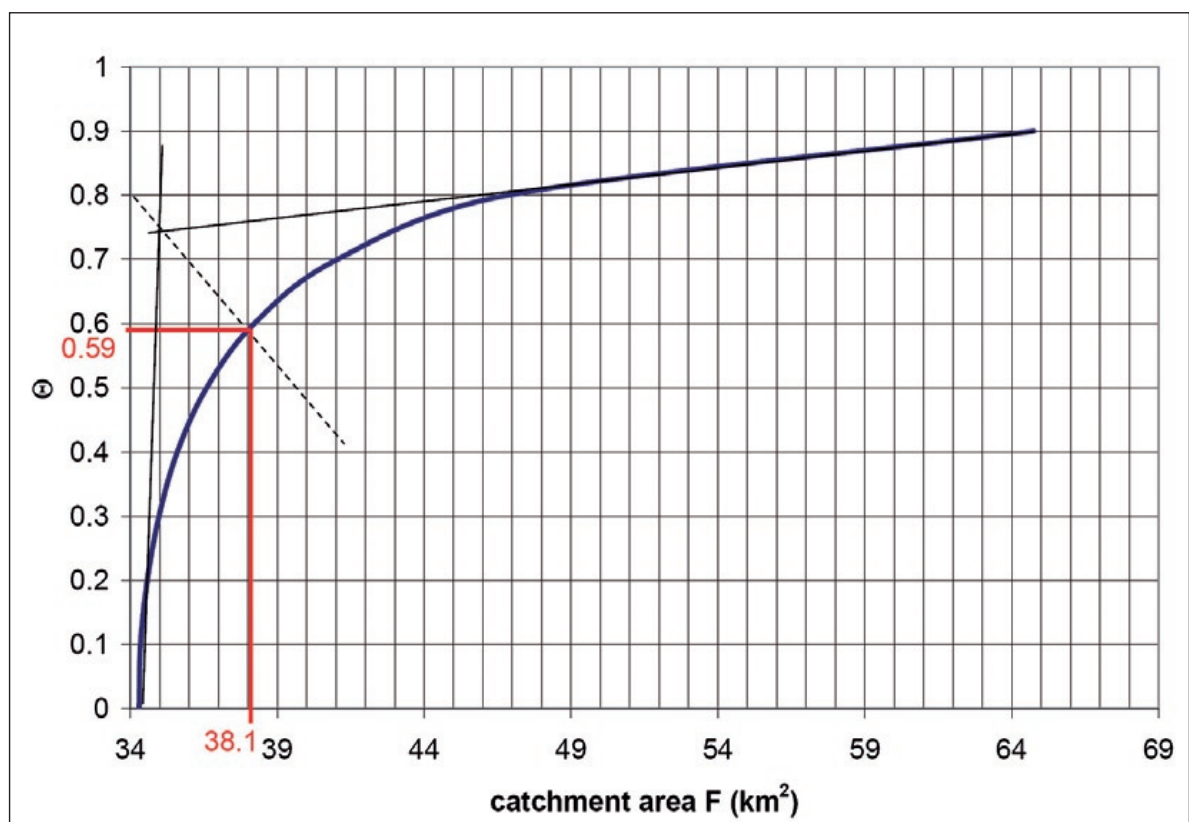

Fig. 6: Diagram $\Theta=f(F)$ for Veliko Vrelo karstic spring.

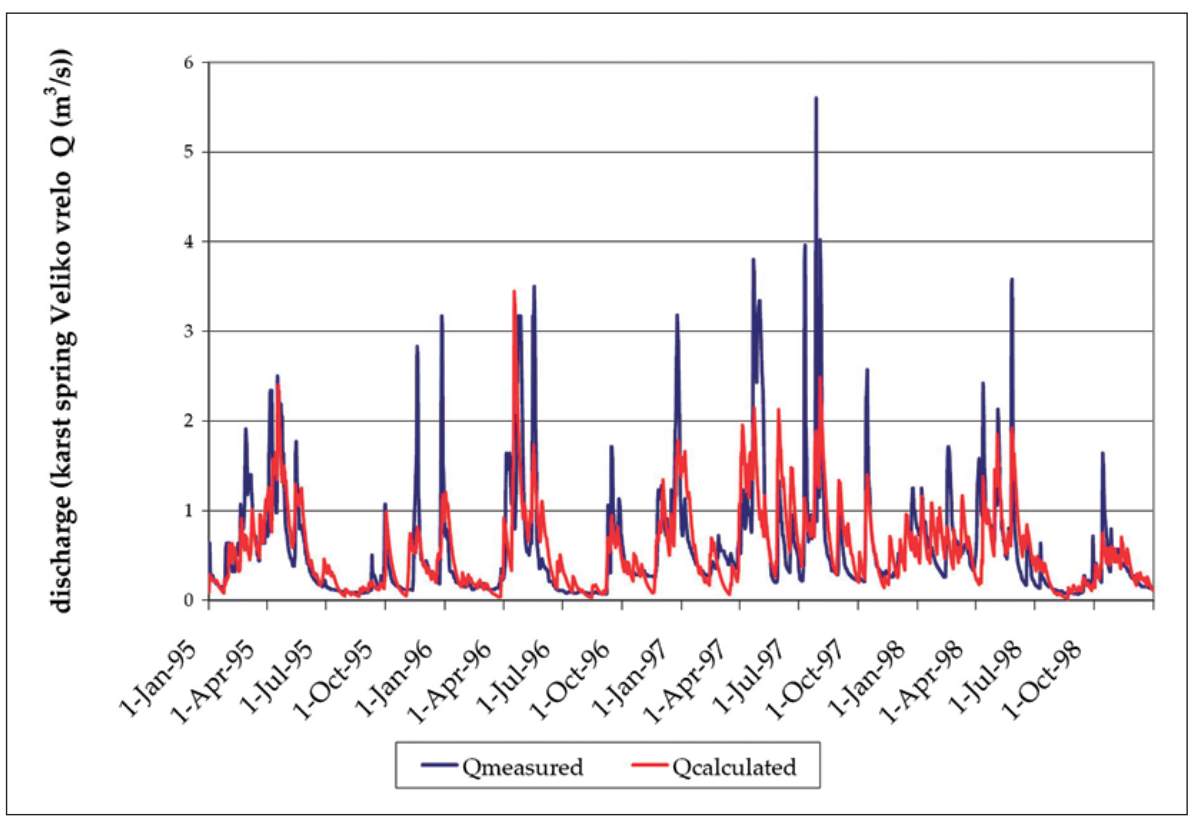

Fig. 7: Simulation of daily discharges of Veliko Vrelo spring.

4. The function $\Theta=f(F)$ allows for the assumption of the size of the catchment area.

\section{RESULTS AND DISCUSSION}

The first step in the stochastic analysis of Veliko Vrelo was the cross correlation of recorded daily discharge values and rainfalls from four nearby climatological stations (Fig. 5).
Following the above presented procedure and established function $\Theta=f(F)$ the Veliko Vrelo catchment is calculated to be $38.1 \mathrm{~km}^{2}$ (Fig. 6). Generally, taking into consideration results of conducted tracing tests and an average springflow of around $0.5 \mathrm{~m}^{3} / \mathrm{s}$, this is an acceptable rate. However, detail field survey and local hydrogeological conditions indicated some 20\% lesser catchment and these differences should be further evaluated.

Once the catchment and "real" evapotranspiration are acquired the simulation of daily spring discharges on the stochastic model is possible. The correlation of real observed values and those simulated for a period of four years (1995-1998) resulted in a coefficient of correlation of 0.69 (Fig. 7). Based on water balance elements i.e., the inflow and outflow relationship, the storage change value $(\Delta V)$ in a karst reservoir could also be obtained by adding and varying the continuous cumulative values to the initial storage (Jemcov 2007). Once the natural storage is estimated, further modeling under a variety of idealized conditions can reveal how the storage may change over time. Various scenarios of artificial interventions and exploitation rates could also include ecological limitations such as guaranteed minimal flow, sustainable flows downstream and tolerable replenishment capacity.

Performed work and a new approach to estimation of the catchment area should be additionally tested and if found feasible could be widely applied in similar studies. 


\section{PHYSICAL MODELLING OF KARSTIC CHANNELS OF KRUPAJA SPRING (SERBIA)}

\section{GENERAL PROBLEM}

There is a gap between exact data obtained from a field survey of the karst surface or from speleology and diving and our knowledge of karst interior. Hydrogeologists are more or less pressured to imagine possible groundwater pathways connected with visible drainage points.

To make this picture possible and somehow accurate, knowledge of the following elements is required:

- lithological units and rock chemistry,

- distribution and size of surficial karst features,

- thickness and texture of epikarst,

- bedding (structure, orientation, slope),

- tectonic pattern,

- soil and vegetation cover,

- speleological objects,

- results of tracing tests,

- position of drainage points.

The knowledge of paleomorphology and hydrography (morphogenesis) is also important because a greater number of created successive paleo conceptual models can facilitate explanation of the current stage of karst development.

3D reconstruction and modelling of karst physical interior is a relatively new approach in karst hydrogeology. Today, powerful GIS software tools enable fast quantitative analysis of collected data (Milanovic S. 2010). Infield survey and data collection can also be condensed and supported by remote sensing. The main advantage of GIS is fast analysis and model creation.

\section{TEST SITE: KRUPAJA SPRING CATCHMENT (SERBIA)}

Krupaja is the large ascending spring in the Carpathian karst of Serbia (average yield is around $1.0 \mathrm{~m}^{3} / \mathrm{s}$ ). It drains thick Cretaceous limestones of the NW slopes of Be- ljanica Mt. The Krupaja main drainage siphon is explored to a depth of $133 \mathrm{~m}$, and is extended deeper (Milanovic S. 2007). The almost vertical shaft is predisposed by the contact with Permian sandstones which were thrust over the limestones during the Miocene. Intensive tectonics was followed by volcanic activity (dacite) and as a result the deep circulation thermal waters $\left(28^{\circ} \mathrm{C}\right)$ discharge in the vicinity of Krupaja spring.

\section{PURPOSE OF STUDY AND CHOSEN METHOD}

By using some of the specialized software based on GIS technology, an approximate calculation of size and volume (storage) of open active voids could easily be computed.

This kind of analysis includes both saturated and unsaturated parts. Measured data could be outlined in three dimensions while display data trends and conduit morphology can be rotated and seen from various angles and inclinations.

Once the volume is calculated the dissolution porosity can be estimated for 3D block containing a conduits system using the standard equation (Kincaid 2006):

$$
\Phi=V c / V b
$$

where:

$\Phi=$ dissolution porosity, $V c=$ volume of karst conduit, $V b=$ volume of the block.

Because this method considers only a single block within the karst aquifer, it is necessary to repeat the calculation at various locations to portray the entire catchment area adequately. This method is applied to the Krupaja main drainage block in order to estimate effective porosity and compare this result with others obtained from neighbouring but less permeable blocks.
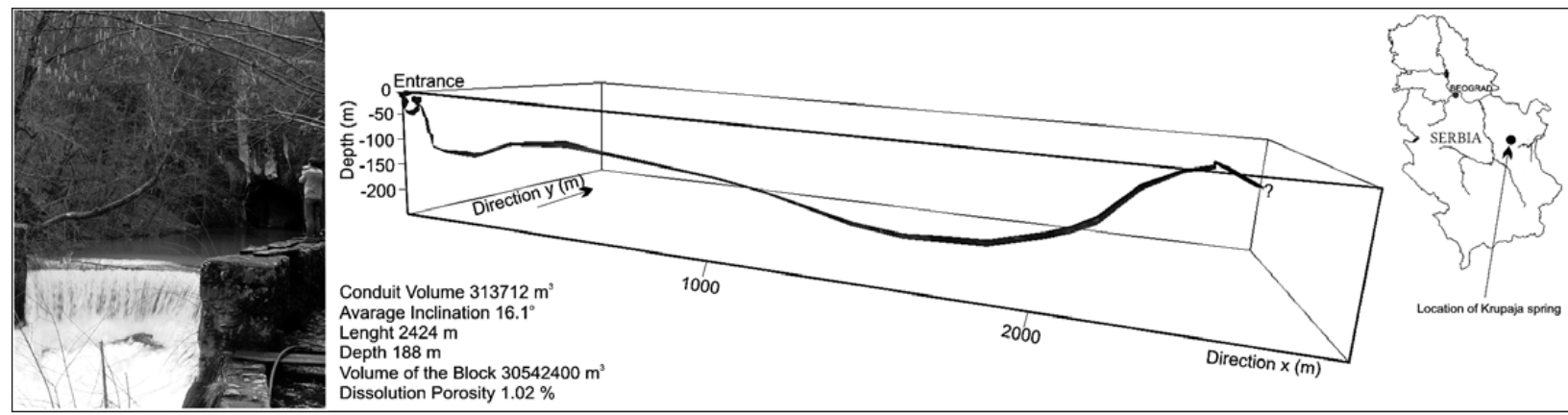

Fig. 8: 3D conduits of Krupaja Spring (Eastern Serbia) with calculated effective (dissolution) porosity (Photo: S. Milanovic). 


\section{RESULTS AND DISCUSSION}

The block, 2,400 $\mathrm{m}$ long, is elongated from the Krupaja karstic spring, i.e. from the contact with impermeable Permian rocks to the karst interior. Keeping in mind the experience obtained from similar karstic terrains in Carpathian karst (Stevanovic \& Dragisic 1997; Milanovic S. 2005), the existence of one main conduit as a preferential path is acknowledged instead of a number of smaller ones (Fig. 8). The lowest part of the main channel reaches a depth of some $200 \mathrm{~m}$, which the local karstification base confirmed by exploratory drilling. The effective porosity of this separate block is calculated on 0.0102. The volume which appears to be less than expected, but still sufficient to transfer a large amount of water percolates from upper layers with matrix porosity (epikarst).

The method is undoubtedly useful. When more input data about karst interior are available as, for example, from speleology or diving (Kincaid 2006) the result is much more realistic and accurate. In contrast, when very little data exists, subjective statements definitely prevail and the results should be used with caution.

\section{MULTI-METHOD RESEARCH OF MLAVA SPRING AND ITS CATCHMENT (SERBIA)}

The Mlava Spring (locally: Vrelo Mlave) is the largest in the Carpathian karst of Eastern Serbia and its potential for regional water supply, including possibly for the suburban area of the state capital of Belgrade, has been evaluated and proposed (Stevanovic et al. 1986). However, because of its distance, some $150 \mathrm{~km}$ from city centre, and a plan, at that time, for a reservoir at the same Mlava River some $50 \mathrm{~km}$ from the spring, this proposal was not realized. Given that this second plan also went to ad acta, a new research programme lasting several years and intended to verify some previous conclusions concerning groundwater reserves as well as opportunities for karst aquifer regulation was initiated. This new programme has included several methods all presented in previous chapters. The chosen methods and their volumes focused on two main dilemmas: effective storage and optimal tapping structure.

The Mlava Spring is situated at the tectonical contact of Aptian limestones of North Beljanica Mt. and Miocene lacustrian sediments of Zagubica basin, a small isolated depression formed between mountain ridges (Fig. 9). The spring water is currently utilized in small amounts for the nearby fishpond. The nearby unpopulated mountains yield excellent water quality, and rarely display any bacteriological contaminations or turbidity.

Mlava is a typical vauclusian spring, with very deep karstic channels. The discharge outlet is located in a lake. The first bathymetrical measurements were done by Jovan Cvijic (1896).

\section{SPELEOLOGY}

Milanovic S. $(2005,2010)$ with his speleological team has conducted an intensive survey of Beljanica Mountain. There are more than 65 surveyed large caves and shafts, some of which are hydrogeologically active, func- tioning as ponors (swallow holes). Tracing tests helped to delineate groundwater divides with the neighboring basins of Resava (on the south) and Krupaja (on the west). Such a catchment at Mlava with 3/4 of karstified carbonate rocks is assumed to be around $158 \mathrm{~km}^{2}$. During the flood episodes when aquifer is fully saturated the runoff is increasing particularly in the eastern part of the catchment and consequently the net recharge area is reducing.

\section{DIVING}

An examination of the main siphon has also been undertaken by Milanovic S. $(2005,2007)$. At a depth of about $33 \mathrm{~m}$, a narrow knee-shaped construction is registered (this was the maximal depth reached by Cvijic's tool); the channel then expands in a vertical funnel-shape and continues even deeper (Figs. 10, 11). It has been explored to a depth of $73 \mathrm{~m}$ (Milanovic S. 2005); because further diving is not possible with the available equipment its bottom has not yet been reached.

\section{DISCHARGE REGIME}

Mlava is one of the very few karstic springs in Serbia where springflow has been observed for a longer period of time (since 1966). Its hydrograph during an average hydrological cycle shows three maximal micro regimes followed by three minima at their ends (Stevanovic 1994, Fig. 12). The first maximum is the most dominant and appears as a consequence of snow melting. The second maximum is connected with a period of intense spring and summer showers (May - July); it is characterized by discharges which are sometimes higher than discharges from the previously mentioned "first" period (snow melting), but peaks are often of shorter duration. 


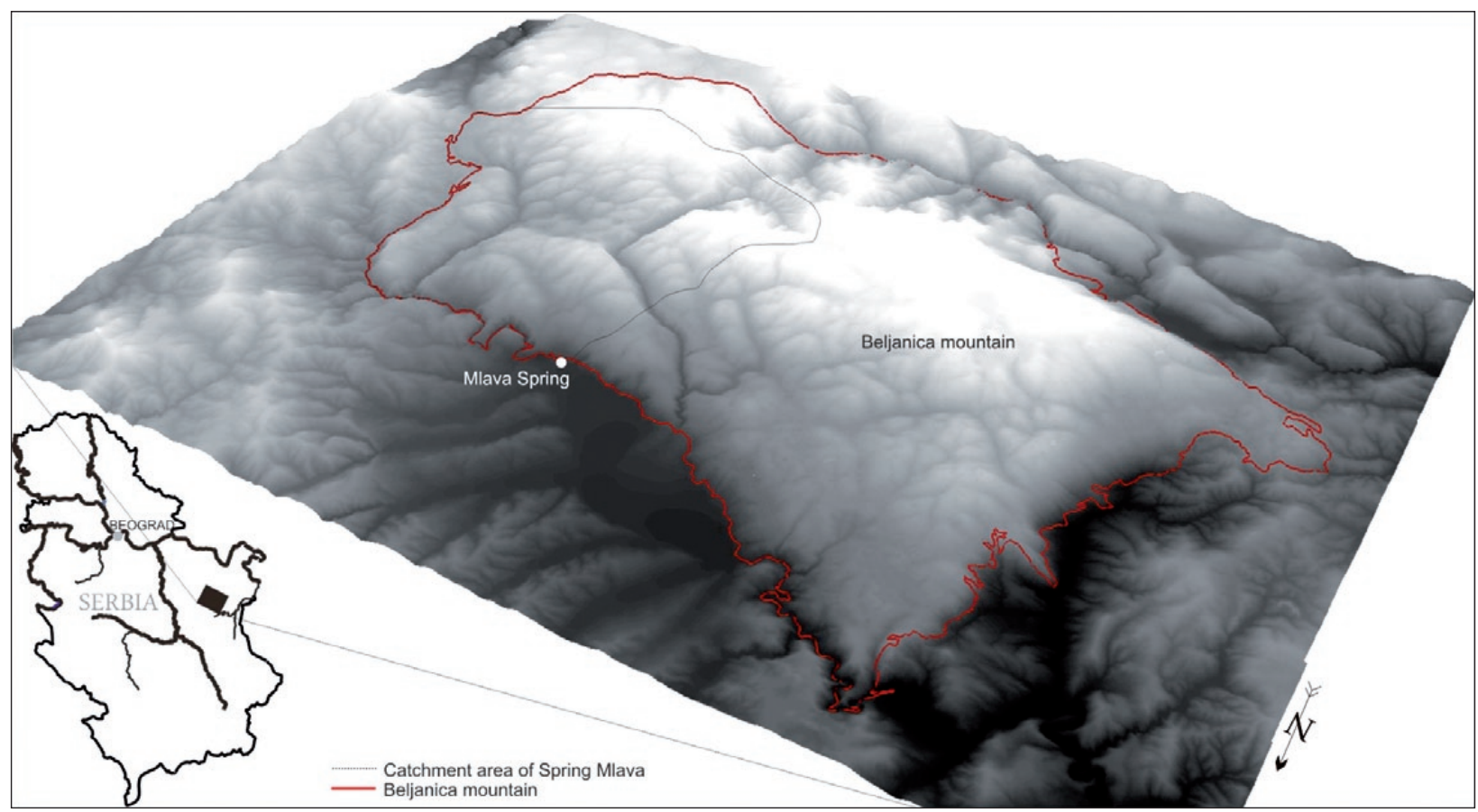

Fig. 9: Location and 3D map of Mlava catchment area in Carpathian karst (Zagubica, Serbia).

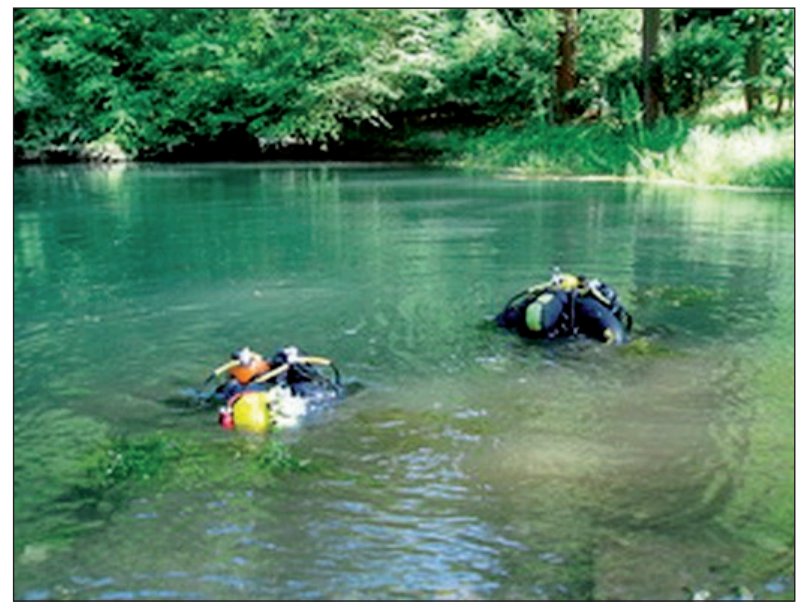

Figs. 10, 11: Diving in Mlava Spring and cross-section of its main siphon (Milanovic S. 2007; Photo: S. Milanovic).

The third maximum appears in November - December, after the main recession period. During this maximum, discharges are less intense because the infiltrated water primary goes to replenishment of discharged dynamic reserves.

The typical average springflow is $1.85 \mathrm{~m}^{3} / \mathrm{s}$, the absolute extreme maximum is $19 \mathrm{~m}^{3} / \mathrm{s}$, while the recorded extreme minimum is equal to $0.215 \mathrm{~m}^{3} / \mathrm{s}$ (Ristic et al. 1997; Ristic 2007). Values of annual average discharges are between $1.01 \mathrm{~m}^{3} / \mathrm{s}$ in 1992 and $3.17 \mathrm{~m}^{3} / \mathrm{s}$ in 1967

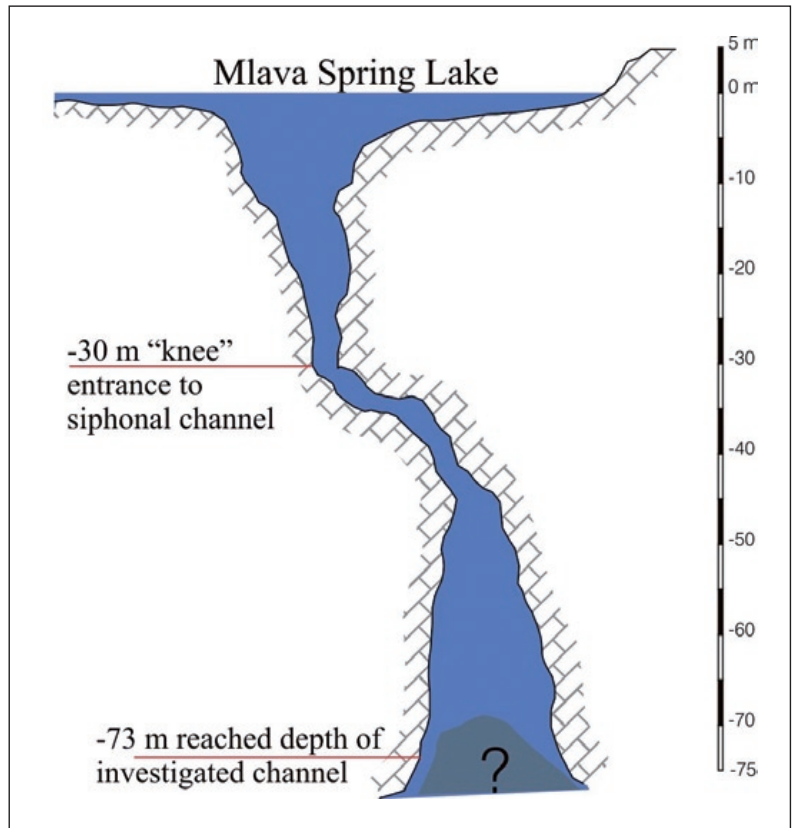

(Fig.13). Maximum monthly discharge values, recorded in April 1984, were $10.6 \mathrm{~m}^{3} / \mathrm{s}$. The minimum, $0.271 \mathrm{~m}^{3} / \mathrm{s}$, was in October 1992. The greatest average monthly discharge is in April with an average value of $4.05 \mathrm{~m}^{3} / \mathrm{s}$. In September the average springflow regularly achieves the annual minimum (about $0.83 \mathrm{~m}^{3} / \mathrm{s}$ ). 


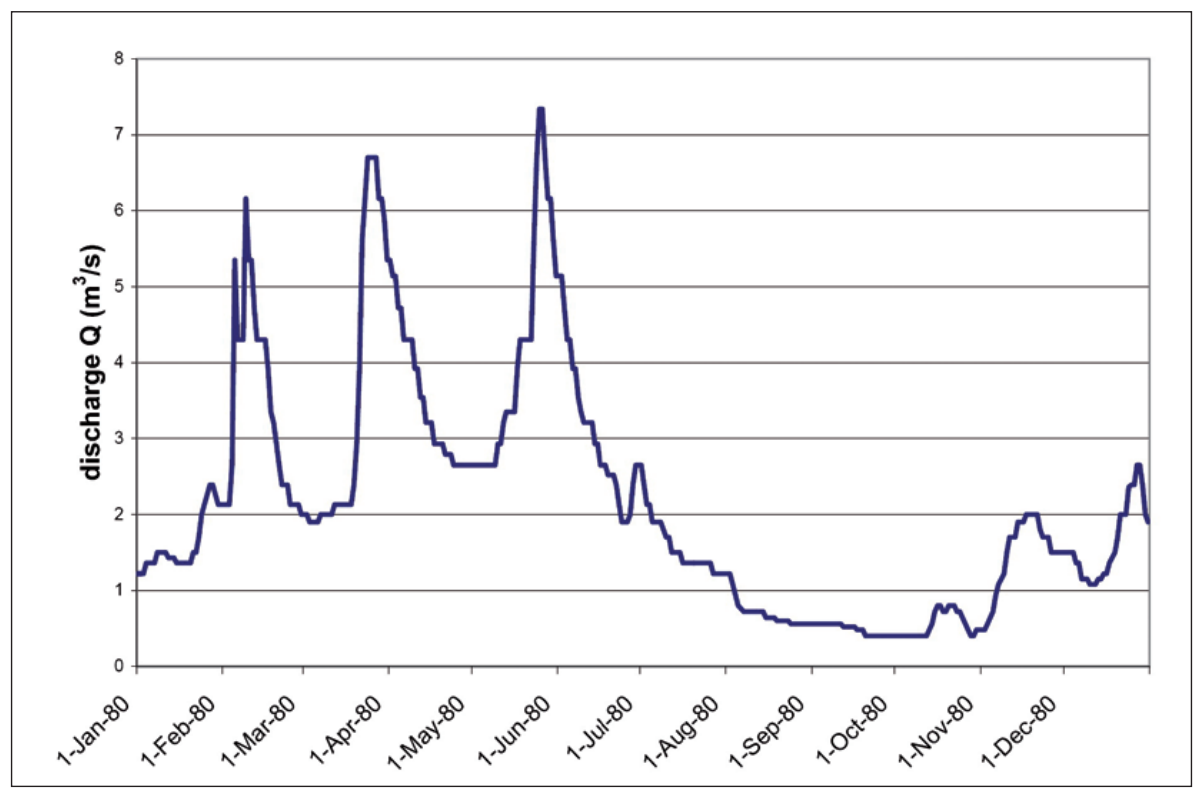

Fig. 12: Spring hydrograph of Mlava Spring for 1980 (after Hydrometeorological Survey of Serbia).

\section{STOCHASTIC ANALYSIS}

The first step taken in order to predict the variation of the reserves within the large Mlava karstic system was the creation of the Multiple Numerical Correlation (MNC) model (Ristic 2007). Then, after simulation of the springflow for a period of 40 years (1961-2000) and obtained values $\mathrm{R}=0.83$, the model was extended to assess the variation of the dynamic storage of karst waters (Fig. 14). The annual variations are the result of a change

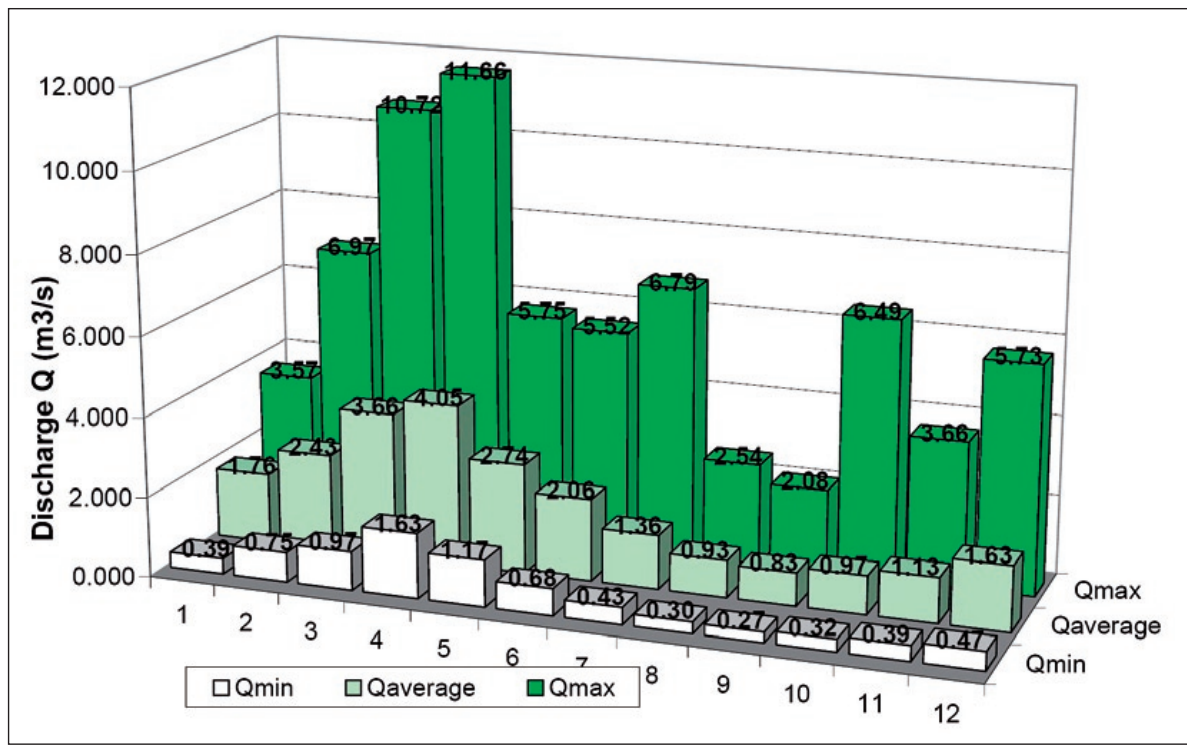

Fig. 13: Minimum, average and maximum monthly discharges (in $\mathrm{m}^{3} / \mathrm{s}$ ) of the Mlava Spring during the period 1961-2000. in climatic parameters such as precipitation, evapotranspiration, humidity, and air temperature. Finally, the very large amplitude (difference of max and min storage) of $293 \times 10^{6} \mathrm{~m}^{3}$ is obtained. This indicates a very large storage in the deeper part and consequently, it was assumed that it is possible to sustain sufficient discharge of up to $0.5 \mathrm{~m}^{3} / \mathrm{s}$ above the minimal "ecological" flow for the next decade without severe negative impact on the environment.

By using the same procedure as in the case of the Veliko Vrelo, the probable catchment of the Mlava Spring has been calculated at about $156 \mathrm{~km}^{2}$ which is very close to the surface obtained by field survey and GIS modelling.

\section{GIS APPLICATION AND ANALYSIS}

An attempt to calculate the effective porosity and volume of stored water is also made by $3 \mathrm{D}$ modelling of saturated karst conduits.

For detailed morphogenetic and hydrogeological analyses Milanovic S. (2010) has developed an authen-

tic BEKI-F-model (acronym of Beljanica karst aquifer physical model) with multiparameters input generated by ArcGIS software. The characterization of the karstic system includes transfer of all 2D data collected in the field into the $3 \mathrm{D}$ model of a potential karst conduit network.

Based on the BEKI$F$ model and geostatistical analyses it was possible to establish the link between karst conduits of the Mlava Spring with the positions of faults, particularly the intersections of faults, bedding planes, orientation of dolines (sinkholes), caves 


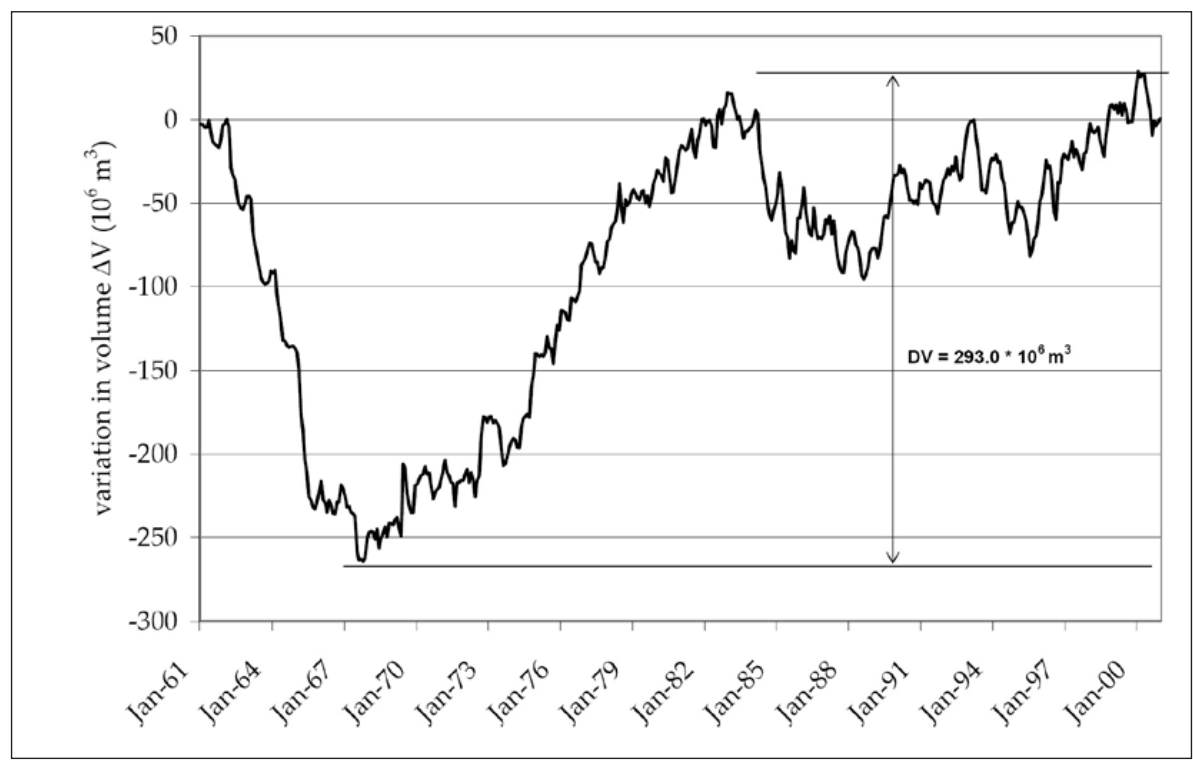

Fig. 14: Variation of dynamic storage of Mlava karst system in 40-year period (Ristic 2007).

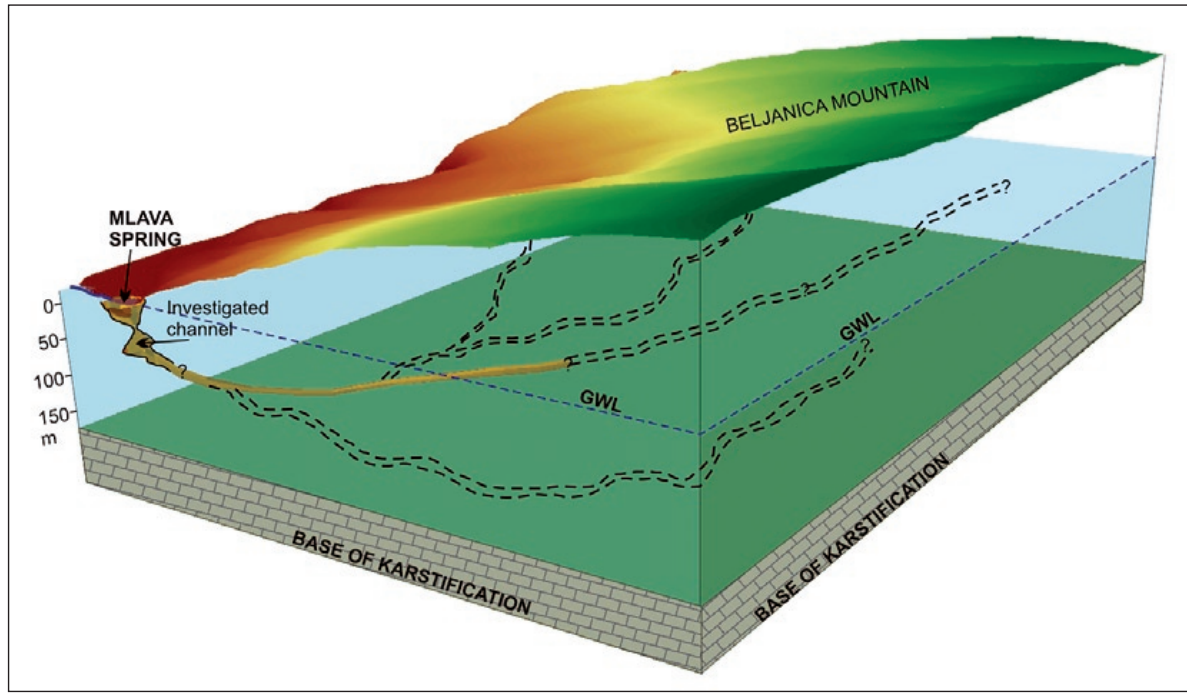

Fig. 15: 3D diagram of supposed net of main channels nearby Mlava discharge zone.

ponor as an entrance to the system, at $1,285 \mathrm{~m}$ asl. The majority of karst conduits and main karstification level is between 80 and $200 \mathrm{~m}$ asl., while the Mlava spring is at the altitude of $314 \mathrm{~m}$ asl. The total length of all mapped karst conduits within the Mlava catchment is around 175,000 m (Fig. 16).

The BEKI-F-model recognizes the dolines as the main infiltration points and it is possible to gain a channel distribution based on doline watersheds. For instance, Fig. 16 shows the potential map of karst conduits created by linking the bottom of each of the 1682 dolines (red dots) on part of Beljanica Mt. with inner junctions of karst system (Milanovic S. 2010).

Such a procedure obviously simplifies the geometry of the major channels and ignores smaller ones, but it represents an important step towards the positioning of karstic pathways and understanding of flow directions. Finally, in terms of this model, the estimated average effective porosity of the Mlava karst aquifer is found to be 0.012 .

The results obtained by various methods reconfirm the existence of a significant

and other hydrogeological data. As always, the most problematic for characterization was the zone between surface and erosional basis, but with a good number of data related to karstification development and intensity, this part has been reconstructed and the pathways traced (Fig. 15).

During the creation of the physical model more than 4,386 junctions were established and posted into the database of the BEKI-F-model. The lowest point of the reconstructed karstic "pipe network" with active groundwater circulation is at $75 \mathrm{~m}$ asl while the highest represents the effective storage of Mlava aquifer and good and fast replenishment potential for the extracted waters. Water tapping is possible by simple gravity intake, while wide and deep drainage siphon and ascending flow enable installation of the pumps which could be activated exclusively during the recession periods. However, further water management analyses and feasibility studies should define the final design of the tapping structure, the extraction rate, the guaranteed flow for water dependent eco-systems and protective measures around the source and in the entire catchment area. 


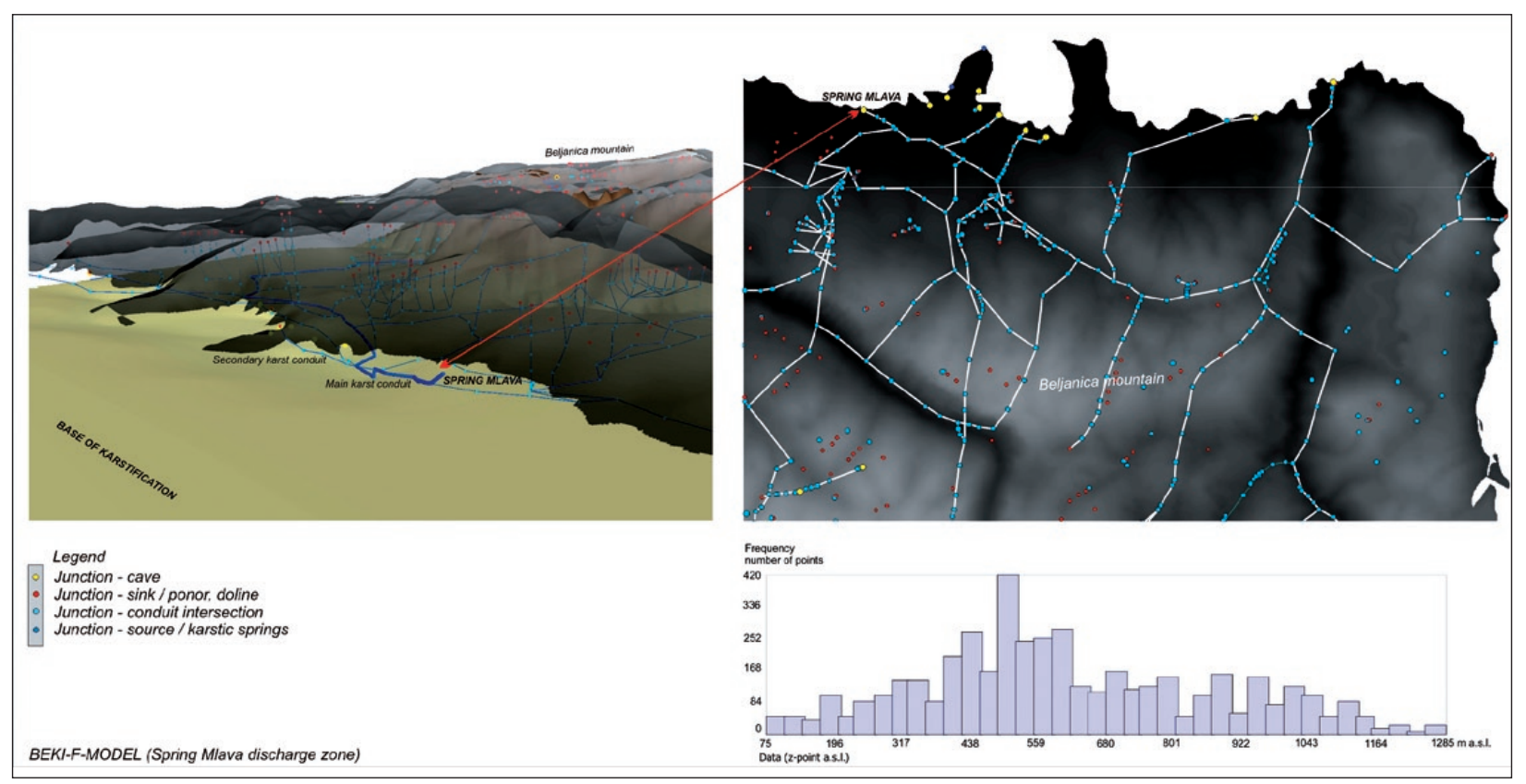

Fig. 16: 2D and 3D karst conduit network of Mlava Spring's catchment in accordance with BEKI-F-model (Milanovic S. 2010).

\section{CONCLUSION}

The key element in engineering projects which aim to assess the potential of a karst aquifer for water supply or for other purposes is the storage capacity (storativity), often identified with effective porosity.

A variety of direct and indirect methods is required to assess this parameter. Some conventional methods such as tracing tests, and geophysical or speleological surveys, provide highly valuable data. Some other methods are not so habitually applied, or are still under evaluation and testing. However, they all should be a logical alternative to the classical methods of assessing storativity after pumping tests which do not provide successful results in the case of karst.

As presented in this paper, the experiences obtained by cave diving survey, camera logging of cavities, stochastic analysis of spring discharge regime and 3D modelling of karst conduits from several test sites confirmed the prospect for wider application of these methods in hydrogeological practice. The first two as direct methods are more exact and enable more concrete technical decisions such given proposals to postpone the tapping of large springs in littoral karst of Montenegro or to prepare very complex protective measures against water leakage from a reservoir under construction in Algeria.

With regard modeling, the integrity of its results depends on the quality of the input data. Stochastic models and GIS software tools for conceptual modelling of karst conduits are increasingly present in our practice and could provide affirmative results, as shown in the two case studies from eastern Serbia. These indirect methods are also inexpensive and the number of options could rapidly be evaluated, which is an excellent support tool in decision-making. Eventually, as more methods are integrated, the chance to obtain positive results increases. An integrated approach comprising four described specialized techniques complemented by traditional methods can reduce project and capital expenditure risks.

Such as the multi-method approach applied in Serbia at the large karstic Mlava Spring. Its effective porosity of 0.012 , obtained by a newly created $3 \mathrm{D}$ conceptual model as well as groundwater reserves obtained by stochastic modelling of $0.5 \mathrm{~m}^{3} / \mathrm{s}$ that can be sustainably extracted without severe ecological consequences, confirm the prospect of Mlava for regional water supply.

The future of karst exploration probably lies in technical innovations, which should enable the identification of the main conduits and flow pattern. The authors of this paper, together with a group of mechanical and electrical engineers, have initiated discussion about techniques for infra red or electro magnetic scanning of karst interior. The principle is based on ground signal registrations including possible use of an existing net of 
satellite receivers. Small, specially constructed transmitters introduced into karst channels will definitely be the future of karst research.

Remote sensing and airborne images also support the search for water-filled caverns and it is expected that the sensitivity and achievements of these methods will be further improved. Nevertheless, use of a thermovisual (heat-sensitive) camera for the identification of differ- ent thermal emitters such as submerged flows entering water bodies (streams, lakes, reservoirs, or sea) can both indicate a masked discharge point and approximate the discharge of inflowing water. More advanced technology will probably offer an opportunity to search for fluids of contrasting temperature or viscosity and their contours in the drainage area.

\section{ACKNOWLEDGEMENTS}

Authors gratefully acknowledge support of Beverly Lynch and Grant Pearce who made this paper more legible.

\section{REFERENCES}

Atkinson, T.C., 1977: Diffuse flow and conduit flow in limestone terrain in the Mendip Hills, Somerset (Great Britain).- Journal of Hydrology, 35, 1-2, 93-110.

Avias, J., 1984 : Captage des sources karstiques avec pompage en période d'étiage. L'exemple de la source du Lez.- In: Burger, A. \& L. Dubertet (eds.) Hydrogeology of karstic terrains. Case histories. Intern. Contrib. to Hydrogeol. IAH, 1, Heise, pp. 117119, Hannover.

Bonacci, O., 1993: Karst spring hydrographs as indicators of karst aquifers.- Hydrological sciences journal, 38, 1, 51-62.

Cvijic, J., 1893: Das Karstphänomen. Versuch einer morphologischen Monographie.- Geographischen Abhandlung, V, 3, pp. 114, Vienna.

Cvijic, J., 1896: Springs, peat bogs and waterfalls in Eastern Serbia II (in Serbian).- Glas of Serbian Royal Academy, pp. 122, Belgrade.

Escolero, O. A., Marin, L. E., Steinich, B., Pacheco, A. J., Cabrera, S. A. \& J. Alcocer, 2002: Development of a protection strategy of karst limestone aquifers: The Merida Yucatan, Mexico case study.- Water Resources management, 16, 5, 351-367.

Goldscheider, N. \& D. Drew, 2007 (eds.): Methods in karst hydrogeology.- Intern. Contrib. to Hydrogeol. IAH, 26, Taylor \& Francis, pp. 276, London.

Goldscheider, N., Meiman, J., Pronk, M. \& C. Smart, 2008: Tracer tests in karst hydrogeology and speleology.- International Journal of Speleology, 37, 1, 27-40.
Ford, D. \& P. Williams, 2007: Karst hydrogeology and geomorphology.- J.Wiley \& Sons, pp. 562, Chichester.

Jemcov, I., 2007: Water supply potential and optimal exploitation capacity of karst aquifer systems.- Envi. Geol., 51, 5, 767-773.

Käss, W., 1998: Tracing technique in geohydrology (Engl. transl. of Geohydrologische markierungstechnik).Balkema, pp. 581, Brookfield.

Kincaid, T. R., 2006: A method for producing 3-D geometric and parameter models of saturated cave systems with a discussion of applications.- In: Sasowskiy, I. \& C. Wicks (eds.) Groundwater flow and contaminant transport in carbonate aquifers. Balkema, pp. 169-190, Rotterdam.

Kresic, N., 2007: Hydrogeology and groundwater modeling.- $2^{\text {nd }}$ edition. CRC Press, Taylor \& Francis, pp. 807 , Boca Raton.

Kresic, N., 2010: Types and classification of springs.- In: Kresic, N. \& Z. Stevanovic (eds.) Groundwater hydrology of springs: Engineering, theory, management and sustainability. Elsevier, pp. 31-84, Amsterdam.

Kullman, E. \& V. Hanzel, 1994: Karst - fissure waters in Mesozoic carbonate rocks of West Carpathians (Slovakia).- In: Stevanovic, Z. \& B. Filipovic (eds.) Ground waters in carbonate rocks of the Carpathian - Balkan mountain range. - Spec. ed. CBGA, Alston, pp. 113-148, Jersey.

Lapierre, L., 2008: Robust diving control of an AUV.Ocean Engineering, 36, 1, 92-104. 
Mangin, A., 1984 : Pour une meilleure connaisance des systèmes hydrologiques à partir des analyses corrélatoire et spectrale.- Journal of Hydrology, 67, 25-43.

Mijatovic, B., 2005: Groundwater discharge in the Mediterranean karst coastal zones and freshwater tapping: set problems and adopted solutions - case studies.- In: Stevanović, Z. \& P. Milanović (eds.) Water resources and environmental problems in karst, Proceedings of the international conference and field seminars, $13^{\text {th }}-19^{\text {th }}$ September 2005 , Belgrade, Kotor. ZUHRA, 259-266, Belgrade.

Milanovic, P., 1979: Hidrogeologija karsta $i$ metode istrazivanja [Karst hydrogeology and research methods].- Spec. ed. HE Trebisnjice, Trebinje.

Milanovic, P., 2000: Geological engineering in karst.- Zebra Publ. Ltd, pp. 347, Belgrade.

Milanovic, P., 2005: Water potential of Southeastern Dinarides.- In: Stevanović, Z. \& P. Milanović (eds.) Water resources and environmental problems in karst, Proceedings of the international conference and field seminars, $13^{\text {th }}-19^{\text {th }}$ September 2005 , Belgrade, Kotor. ZUHRA, 249-257, Belgrade.

Milanovic, P., Stevanovic, Z. \& V. Belicevic, 2007: Barrage Hammam Grouz, Saf Saf, Ourkiss. - Raport d'expertise, ANBT, pp 97, Alger.

Milanovic, S., 2005: Underground karst morphology for applied hydrogeology purpose.- MS thesis, Dept. of Hydrogeol. FMG, University of Belgrade, pp. 184.

Milanovic, S., 2007: Hydrogeological characteristics of some deep siphonal springs in Serbia and Montenegro karst.- Envi. Geol., 51, 5, 755-760.

Milanovic, S., Stevanovic, Z. \& I. Jemcov, 2010: Water losses risk assessment: an example from Carpathian karst.- Environmental Earth Sciences, 60, 4, 817-830.

Milanovic, S., 2010: Creation of physical model of karst aquifer on example of Beljanica Mt. (Eastern Serbia).- Doct. dissert. (draft), Dept. of Hydrogeol. FMG, University of Belgrade, pp. 339.

Padilla, A., Pulido-Bosch, A. \& A. Mangin, 1994: Relative importance of baseflow and quickflow from hydrographs of karst spring.- Ground Water, 32, 2, 267.

Panagopoulos, G. \& N. Lambrakis, 2006: The contribution of time series analysis to the study of the hydrodynamic characteristics of the karst systems: Application on two typical karst aquifers of Greece (Trifilia, Almyros Crete).- Journal of Hydrology, 329, 368-376.

Peric, J., Simic, M. \& M. Milivojevic, 1980: An idea to storing part of Beli Drim water within underground reservoirs for water supply and irrigation of Metohija (in Serbian).- Transactions of FMG, 22, 251-292, Belgrade.
Potie, L. \& B.Tardieu, 1977: Development of submarine springs.- In: Tolson, J.S. \& F.L. Doyle (eds.) Karst hydrogeology. University of Alabama at Huntsville Press, pp. 39-48, Huntsville.

Prohaska, S., 2003: Hidrologija I deo. Hidro-meteorologija, hidrometrija $i$ vodni režim [Hydrology I part. Hydro-meteorology, hydrometry and water regime].- Spec. ed. FMG, Institute "Jaroslav Cerni" and RHMZ Serbia, pp. 556, Belgrade.

Ristic, V., Stevanovic, Z. \& S. Prohaska, 1997: Some examples of karst springflow regime simulation and prediction for water management balance analyses.- Theoretical and Applied Karstology, Academia Romana, 9, 141-149.

Ristic, V., 2007: Development of simulation model for calculating daily discharges of the karst springs.- Doct. dissert., Dept. of Hydrogeol. FMG, University of Belgrade, pp. 359.

Stevanovic, Z., Filipovic, B. \& I. Stevanovic, 1986: Opportunities to tap karstic groundwater from the Upper Mlava catchment for Belgrade or other consumers (in Serbian).- Voda i sanitarna tehnika, VI, 17-26.

Stevanovic, Z.,1994: Karst ground waters of CarpathoBalkanides in Eastern Serbia.- In: Stevanovic, Z. \& B. Filipovic (eds.). Ground waters in carbonate rocks of the Carpathian - Balkan mountain range. Spec. ed. of CBGA, Allston Publ., pp. 203-237, Jersey

Stevanovic, Z. \& V. Dragisic, 1997: An example of regulation of karst aquifer.- In: Gunay, G. \& I. Johnson (eds.) Karst waters and environmental impacts. Balkema, pp. 19-26, Rotterdam.

Stevanovic, Z. \& V. Dragisic, 1998: An example of identfying karst groundwater flow.- Envi geol., 35, 4, 241244.

Stevanović, Z., Jemcov I. \& S. Milanovic, 2007: Management of karst aquifers in Serbia for water supply.Envi. Geol., 51, 5, 743-748.

Stevanovic, Z., 2010: Utilization and regulation of springs.- In: Kresic, N. \& Z. Stevanovic (eds.). Groundwater hydrology of springs: Engineering, theory, management and sustainability. Elsevier, pp. 341-389, Amsterdam.

Toulomudjian, C., 2005: The springs of Montenegro and Dinaric karst.- In: Stevanović, Z. \& P. Milanović (eds.) Water resources and environmental problems in karst, Proceedings of the international conference and field seminars, $13^{\text {th }}-19^{\text {th }}$ September 2005, Belgrade, Kotor. ZUHRA, 443-450, Belgrade.

Yaoru, L., Jie, X.A. \& S.H. Zhang, 1973: The development of karst in China and some of its hydrogeological and engenireeng geological conditions.- Acta Geologica Sinica, 1, 121-136. 
